\title{
Temporal variability of the NPP-GPP ratio at seasonal and interannual time scales in a temperate beech forest
}

\author{
M. Campioli ${ }^{1}$, B. Gielen ${ }^{1}$, M. Göckede ${ }^{2}$, D. Papale ${ }^{3}$, O. Bouriaud ${ }^{4}$, and A. Granier ${ }^{5}$ \\ ${ }^{1}$ Department of Biology, University of Antwerp, Wilrijk, Belgium \\ ${ }^{2}$ Department of Forest Ecosystems and Society, Oregon State University, Corvallis, USA \\ ${ }^{3}$ Department for Innovation in Biological, Agro-food and Forest systems, University of Tuscia, Viterbo, Italy \\ ${ }^{4}$ Research Station for Norway Spruce Silviculture, Forest Research and Management Institute-ICAS, Campulung \\ Moldovonesc, Romania \\ ${ }^{5}$ Forest Ecology and Ecophysiology Unit, UMR INRA UHP, Champenoux, France
}

Received: 21 September 2010 - Published in Biogeosciences Discuss.: 19 October 2010

Revised: 5 August 2011 - Accepted: 5 August 2011 - Published: 6 September 2011

\begin{abstract}
The allocation of carbon (C) taken up by the tree canopy for respiration and production of tree organs with different construction and maintenance costs, life span and decomposition rate, crucially affects the residence time of $\mathrm{C}$ in forests and their $\mathrm{C}$ cycling rate. The carbon-use efficiency, or ratio between net primary production (NPP) and gross primary production (GPP), represents a convenient way to analyse the $\mathrm{C}$ allocation at the stand level. In this study, we extend the current knowledge on the NPP-GPP ratio in forests by assessing the temporal variability of the NPP-GPP ratio at interannual (for 8 years) and seasonal (for 1 year) scales for a young temperate beech stand, reporting dynamics for both leaves and woody organs, in particular stems. NPP was determined with biometric methods/litter traps, whereas the GPP was estimated via the eddy covariance micrometeorological technique.

The interannual variability of the proportion of $\mathrm{C}$ allocated to leaf NPP, wood NPP and leaf plus wood NPP (on average $11 \% \mathrm{yr}^{-1}, 29 \% \mathrm{yr}^{-1}$ and $39 \% \mathrm{yr}^{-1}$, respectively) was significant among years with up to $12 \% \mathrm{yr}^{-1}$ variation in NPP-GPP ratio. Studies focusing on the comparison of NPP-GPP ratio among forests and models using fixed allocation schemes should take into account the possibility of such relevant interannual variability. Multiple linear regressions indicated that the NPP-GPP ratio of leaves and wood significantly correlated with environmental conditions. Previous year drought and air temperature explained about half of the NPP-GPP variability of leaves and wood, respectively,
\end{abstract}

Correspondence to: M. Campioli (matteo.campioli@ua.ac.be) whereas the NPP-GPP ratio was not decreased by severe drought, with large NPP-GPP ratio on 2003 due mainly to low GPP. During the period between early May and mid June, the majority of GPP was allocated to leaf and stem NPP, whereas these sinks were of little importance later on. Improved estimation of seasonal GPP and of the contribution of previous-year reserves to stem growth, as well as reduction of data uncertainty, will be of relevance to increase the accuracy of the seasonal assessment of the NPP-GPP ratio in forests.

\section{Introduction}

Forest ecosystems account for $52 \%$ of the total terrestrial carbon (C) sink (Grace, 2004) and are of crucial importance in re-absorbing $\mathrm{CO}_{2}$ emissions from anthropogenic activities (Bonan, 2008; Ciais et al., 2008). Despite the extensive research efforts in quantifying the $\mathrm{C}$ exchange between forests and the atmosphere, many open questions remain on the fate of the $\mathrm{C}$ in the ecosystem once taken up by the leaves i.e. the process of $\mathrm{C}$ allocation. In fact, $\mathrm{C}$ (assimilates) allocation is ignored in many studies of ecosystem $\mathrm{C}$ cycling because of its complexity: $\mathrm{C}$ allocation is the outcome of many processes which ultimately involve all the internal, environmental and genetic factors that regulate plant subsistence and development (Cannell and Dewar, 1994). Nevertheless, C allocation among plant processes (e.g. respiration, biomass production) and organs (e.g. leaves, stem) is a key process in the $\mathrm{C}$ cycle because it determines the residence time and location of $\mathrm{C}$ in the ecosystem. For example, $\mathrm{C}$ used for maintenance respiration returns to the atmosphere within a

Published by Copernicus Publications on behalf of the European Geosciences Union. 
timespan ranging between few hours and a few days; $\mathrm{C}$ allocated to structural biomass of organs with high turnover and decomposition rate, such as deciduous leaves, returns to the atmosphere after a few months to a few years, whereas $\mathrm{C}$ allocated to organs with lower turnover and decomposition rate, such as stem wood, returns to the atmosphere only after decades or centuries. In other words, allocation crucially determines the long-term rate of ecosystem respiration, the major C flux released by ecosystems (Trumbore, 2006).

Carbon allocation in plants can be assessed directly by following the fate of $\mathrm{C}$ isotopes $\left(\mathrm{C}^{13}\right.$ and $\left.\mathrm{C}^{14}\right)$ once taken up by the leaves (i.e. isotope labelling). This technique allows a very detailed description of $\mathrm{C}$ allocation but its application to high stature vegetation (e.g. forest stands) to obtain quantitative estimates at seasonal and annual scale is challenging. Alternatively, $\mathrm{C}$ allocation can be derived indirectly by integrating ecosystem $\mathrm{C}$ fluxes obtained from independent methods (Granier et al., 2000; Gough et al., 2008; Ohtsuka et al., 2009), e.g. by combining vegetation $C$ uptake (through assessment of gross primary production, GPP), vegetation C release (through assessment of autotrophic respiration) and $\mathrm{C}$ allocated to biomass production (through assessment of organ-specific net primary production, NPP).

A way to analyse the ecosystem $\mathrm{C}$ fluxes creating the $\mathrm{C}$ allocation pattern in forests is through the study of the NPPGPP ratio, also called the carbon-use efficiency (DeLucia et al., 2007). This ratio has many qualities: (i) it is intuitive, (ii) it is easily comparable among different forest types, (iii) it is applicable to total NPP or to the NPP of the different tree organs separately, (iv) it is applicable at different temporal scales and (v) it is readily usable in models. Therefore the opportunity to model the allocation pattern by combining stand GPP (photosynthesis is a process relative well understood and accurately modelled; Farquhar et al., 1980) and biome-specific NPP-GPP ratios is appealing (Landsberg and Waring, 1997; Thornley and Cannell, 2000; Mäkelä and Valentine, 2001). The study of the NPP-GPP ratio and its possible uniformity across forest types (Waring et al., 1998) has been revised recently by DeLucia et al. (2007) for about 60 sites. However, in most of the studies reviewed, the analysis of the NPP-GPP ratio had limitations as (i) it was restricted to annual scale assessment with little information about interannual variability or seasonal dynamics, (ii) little attention was given to the difference in NPP-GPP ratio among different tree organs and (iii) there were technical imperfections because values of GPP were often not independent of NPP (i.e. GPP derived from NPP measurements) or modelled.

The general objective of this study was to elucidate the temporal dynamics of the allocation of $\mathrm{C}$ taken up through photosynthesis (GPP) by analysing the NPP of a temperate deciduous stand dominated by European beech (Fagus sylvatica $\mathrm{L}$.). We investigated the temporal variability of the NPP-GPP ratio for leaves and wood (branches, stems and coarse roots) on timescales ranging from seasonal to inter- annual. Annual tree organ NPP was assessed by biometric methods or litter collection; seasonal production was inferred from repeated measurements of stem characteristics (e.g. circumference and wood density) and leaf canopy traits (e.g. leaf area index, specific leaf biomass), whereas GPP was derived from continuous micrometeorological measurements through the eddy covariance (EC) methodology.

\section{Materials and methods}

\subsection{Study site}

The study took place at the Hesse forest in North-Eastern France $\left(48^{\circ} 40^{\prime} \mathrm{N}, 7^{\circ} 05^{\prime} \mathrm{E}\right.$; $305 \mathrm{~m}$ a.s.l.; slope $\left.<5 \%\right)$, a site intensively investigated in the fields of forest ecology, meteorology, biogeochemistry and tree science, and part of the European carbon flux monitoring network CarboEurope IP. The region has a semi-continental climate with long-term means of annual temperature and precipitation of $9.2^{\circ} \mathrm{C}$ and $820 \mathrm{~mm}$, respectively. Annual and growing season temperature and precipitation for the study period are reported in Table 1 . The annual allocation dynamics were investigated from 1997 until 2004, whereas the seasonal allocation dynamics were analysed for 1998.

The investigated stand is located in the central part of the Hesse forest. The stand is composed of $90 \%$ young European beech (31 years old in 1997), with Carpinus betulus L. as second most common species, and only sparse understory vegetation. The stand originated from natural regeneration after clear-cutting a mature beech stand on 1965. A standard management (performed by the French forest service, ONF) for young high forests is applied with a thinning every five to six years, removing $\sim 25 \%$ of the basal area. Thinnings were performed one year before the study period (end 1995), during the study period (March 1999) and just after that (March 2005). An exceptional storm hit the area on 26 December 1999 (peak wind speed $\sim 170 \mathrm{~km} \mathrm{~h}^{-1}$ ) but did not damage the trees within the EC footprint (Granier et al., 2008). Overall, the stem density decreased from 4450 tree ha $^{-1}$ in 1997 to 3161 tree ha $^{-1}$ in 2004 (Fig. 1). Between 1997 and 2004, dominant tree height (average tree height of the $10 \%$ tallest trees) increased from 14.7 to $17.5 \mathrm{~m}$, whereas mean diameter at breast height (DBH) increased from 7.0 to $9.2 \mathrm{~cm}$ (Granier et al., 2008). At the site, the soil is lu$\mathrm{visol} /$ stagnic luvisol (FAO classification) with an oligo-mull humus. Clay contents are about $25-35 \%$ within $0-100 \mathrm{~cm}$ depth and about $40 \%$ below $100 \mathrm{~cm}$. Water content at field capacity reaches $0.4 \mathrm{~m}^{3} \mathrm{~m}^{-3}$ in the upper layers. For more details see Epron et al. (1999); Granier et al. (2000, 2008).

\subsection{Gross Primary Production}

Ecosystem GPP was derived from net ecosystem exchange (NEE) measured with the eddy covariance technique (Baldocchi and Meyers, 1998). The EC system consisted of a three dimensional sonic anemometer (Model SOLENT R2, 
Table 1. Annual- and growing season air temperature (mean), precipitation (sum), global radiation (mean) and drought intensity (index) at the beech stand of Hesse during the study period.

\begin{tabular}{llllllllll}
\hline variable & period & 1997 & 1998 & 1999 & 2000 & 2001 & 2002 & 2003 & 2004 \\
\hline \multirow{2}{*}{ air temperature $\left({ }^{\circ} \mathrm{C}\right)$} & annual & 11.4 & 10.8 & 11.6 & 12.7 & 11.3 & 9.7 & 10.7 & 10.5 \\
\multirow{2}{*}{ precipitation $(\mathrm{mm})$} & May-August & 16.4 & 16.4 & 16.6 & 16.5 & 17.1 & 16.1 & 19.3 & 16.6 \\
\cline { 2 - 8 } & annual & 871 & 974 & 1091 & 1017 & 1151 & 914 & 660 & 1158 \\
global radiation $\left(\mathrm{MJ} \mathrm{m}^{-2} \mathrm{~d}^{-1}\right)$ & May-August & 362 & 252 & 354 & 398 & 285 & 255 & 212 & 329 \\
\cline { 2 - 8 } & annual & 11.2 & 10.1 & 10.3 & 11.6 & 11.2 & 11.2 & 13.3 & 11.4 \\
drought intensity index (-) (a) & May-August & 18.0 & 17.9 & 17.8 & 19.2 & 20.1 & 18.5 & 21.5 & 18.7 \\
\cline { 2 - 8 } & annual & 3.9 & 10.7 & 0.0 & 0.0 & 11.1 & 0.0 & 76.8 & 34.0 \\
& May-August & 3.8 & 10.7 & 0.0 & 0.0 & 11.0 & 0.0 & 40.0 & 23.4 \\
\hline
\end{tabular}

(a) low values indicate low level of drought, large values indicate severe drought (90-100: most severe drought at annual scale) (Bréda et al., 2006).

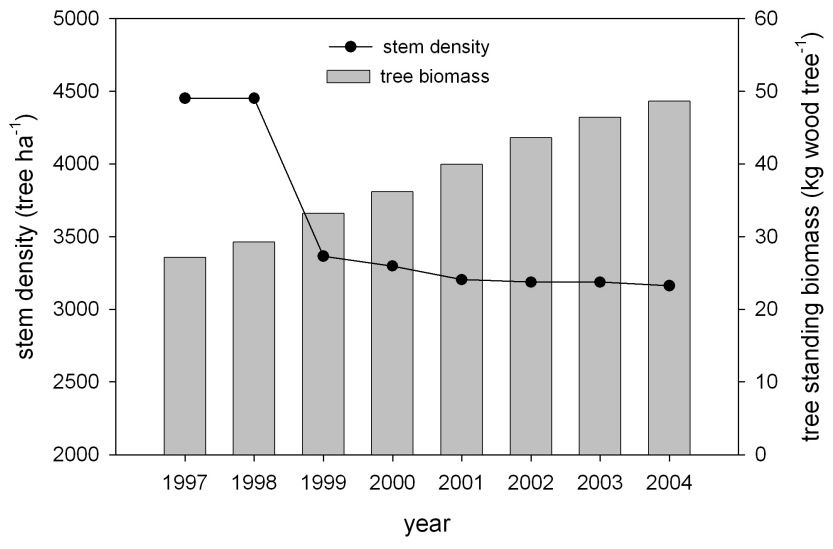

Fig. 1. Stem density and tree standing wood biomass at the beech stand of Hesse during the study period.

Gill Instruments, Lymington, UK) for wind speed and an infrared gas analyser (IRGA) (Model LI-6262, LI-COR Inc., Lincoln, USA) to measure the $\mathrm{CO}_{2}$ concentrations. The measurements were conducted at the top of the canopy at $18.5 \mathrm{~m}$ (1997-1999) and $23 \mathrm{~m}$ (2000-2004). The change in measurement height in spring 2000 was accompanied by a replacement of the eddy-covariance instrumentation after destruction of the tower during the storm in December 1999 (see above). For a detailed description of the experimental setup see Granier et al. (2008).

We considered two series of NEE data, i.e. footprint corrected NEE $\left(\mathrm{NEE}_{\mathrm{f}}\right)$ and non-footprint corrected NEE $\left(\mathrm{NEE}_{\mathrm{nf}}\right)$. At Hesse, the land cover structure in the immediate vicinity of the tower is almost exclusively composed of beech forest, which is the target land cover type. Accordingly, for about $85 \%$ of all half-hourly NEE (data from May-July 2003), $80 \%$ or more of the measured flux signal is ascribed to the target land cover type (Göckede et al., 2008), and can be labelled "representative measurements". However, there are some small agricultural patches in the nearfield of the tower, and coniferous stands are interspersed into the Hesse forest at fetch distances greater than $500 \mathrm{~m}$, which may bias the targeted flux signals. $\mathrm{NEE}_{\mathrm{f}}$ removes uncertainty due to this small scale heterogeneity, and thus helps filtering out the disturbed flux signals. Footprint correction consisted in filtering out half-hourly NEE data with a flux contribution from beech stands smaller than $80 \%$. The footprint analysis is based on a forward Lagrangian Stochastic model (Thomson, 1987) and follows the methodology proposed by Göckede et al. (2008).

Processing of NEE comprised quality checking plus gapfilling and partitioning in GPP and ecosystem respiration $\left(R_{\text {eco }}\right)$. Spikes in the storage corrected fluxes were removed and the dataset filtered for low turbulence conditions as described in Papale et al. (2006). Gapfilling was done with two methods, the marginal distribution sampling (MDS; Reichstein et al., 2005) and the artificial neural network (ANN; Papale et al., 2003). MDS derives missing NEE using the covariation of fluxes with meteorological variables and the temporal auto-correlation of the fluxes (i.e. a moving look-up table centred on each single gap), whereas ANN is a purely empirical non-linear regression model. Both methods showed performances above average in a gap-filling methods comparison (Moffat et al., 2007) and are implemented as standard methods in the European and Fluxnet databases. Partitioning was done with the short term air temperature regression method (Reichstein et al., 2005). In total, four GPP estimates were thus available: GPP-MDS $\mathrm{f}_{\mathrm{f}}$, GPP-MDS $\mathrm{Mf}_{\mathrm{nf}}$, GPP-ANN $\mathrm{AN}_{\mathrm{f}}$ and GPP-ANN $\mathrm{Af}_{\mathrm{nf}}$. Furthermore, to evaluate the uncertainty introduced by the partitioning method used, a second technique based on light-response curve (Lasslop et al., 2010) was applied on the footprint filtered data, obtaining a fifth estimate of GPP, GPP- $\mathrm{L}_{\mathrm{f}}$. Annual and seasonal values of GPP used in the NPP-GPP analysis are means of those five GPP estimates. The non-footprint corrected GPP are presented side-by-side with the footprint-corrected GPP to evaluate the validity of the chosen footprint model setup (e.g. model parameters and model input) and the plausibility of the footprint filter. 


\subsection{Annual and seasonal wood production}

Tree circumferences were available for each of the study years from forest inventories at a representative sub-plot of 0.12 ha (Granier et al., 2008). Annual production of stems, branches and coarse roots (in $\mathrm{kg} \mathrm{ha}^{-1} \mathrm{yr}^{-1}$ ) was calculated from two consecutive estimates of circumference using allometric relationships between DBH $(x)$ and standing biomass $(y)$. Site-specific allometric relationships of the form $y=a x^{b}$ were derived from published datasets of tree organ biomass vs. DBH (Le Goff and Ottorini, 2000; Le Goff and Ottorini, 2001) for stems ( $a=0.192, b=2.20)$, branches $(a=0.00646 ; b=2.81)$ and coarse roots $(a=0.0220 ; b=$ $2.50)\left(p<0.001, R^{2}>0.95\right)$. Production was converted in $\mathrm{kg} \mathrm{Cha}^{-1} \mathrm{yr}^{-1}$ by using $\mathrm{C}$ contents determined at the site for each woody organ in 1999-2000: $46 \%$ for stem, $47 \%$ for branches and $48 \%$ for coarse roots (Barbaroux et al., 2003). Bias introduced by overlooking interannual differences in wood density and $\mathrm{C}$ content are assumed minor as interannual variation in wood density (maximal variation from the mean of 6-7\%; Bouriaud et al., 2004) and in C content percentage (maximal variation from the mean $<1 \%$; Bouriaud unpublished) is limited at the site.

Estimation of the seasonal stem biomass production was derived from seasonal measurements of stem circumference and wood density. The seasonal increase of stem circumference is available from 1996 based on manual measurements at breast height done in the same sub-plot investigated for annual increase in stem biomass (Granier et al., 2008). Measurements were available at intervals of 7-15 days during the period of fast growth (May and June) and at intervals of 1-2 months after this period (Granier et al., 2008). For 1998, additional data about stem circumference increment were available in Barbaroux and Bréda (2002). For examples of typical seasonal circumference increments see Fig. $2 b$ and Granier et al. (2008). For each interval considered for stem circumference increment, the proportional contribution to the annual biomass increment $\left(B_{i} \%\right)$ was assumed equal to the proportional contribution to the annual circumference increment $\left(C_{i} \%\right)$ :

$B_{i} \%=C_{i} \%=\frac{c_{i}-c_{i-1}}{c_{f}-c_{0}}$

where $c_{\mathrm{f}}$ is the circumference at the end of the growing season, $c_{0}$ the circumference at the onset of the growing season, $c_{i}$ and $c_{i-1}$ the stem circumference at two consecutive sampling date $i$ and $i-1$, respectively. Such intra-seasonal values of relative biomass production were transformed to absolute values $\left(B_{i}\right.$; in $\left.\mathrm{kg} \mathrm{Cha}^{-1} \mathrm{~d}^{-1}\right)$ for the corresponding interval by multiplication with the annual value of biomass production $\left(B_{t}\right)$ and corrected for the seasonal variability in stem wood density:

$B_{i}=\alpha_{i} \cdot B_{i} \% \cdot B_{t}$

where $\alpha_{i}$ is a correcting factor (varying from 0.96 to 1.36 ) calculated from the stem wood density in the period between

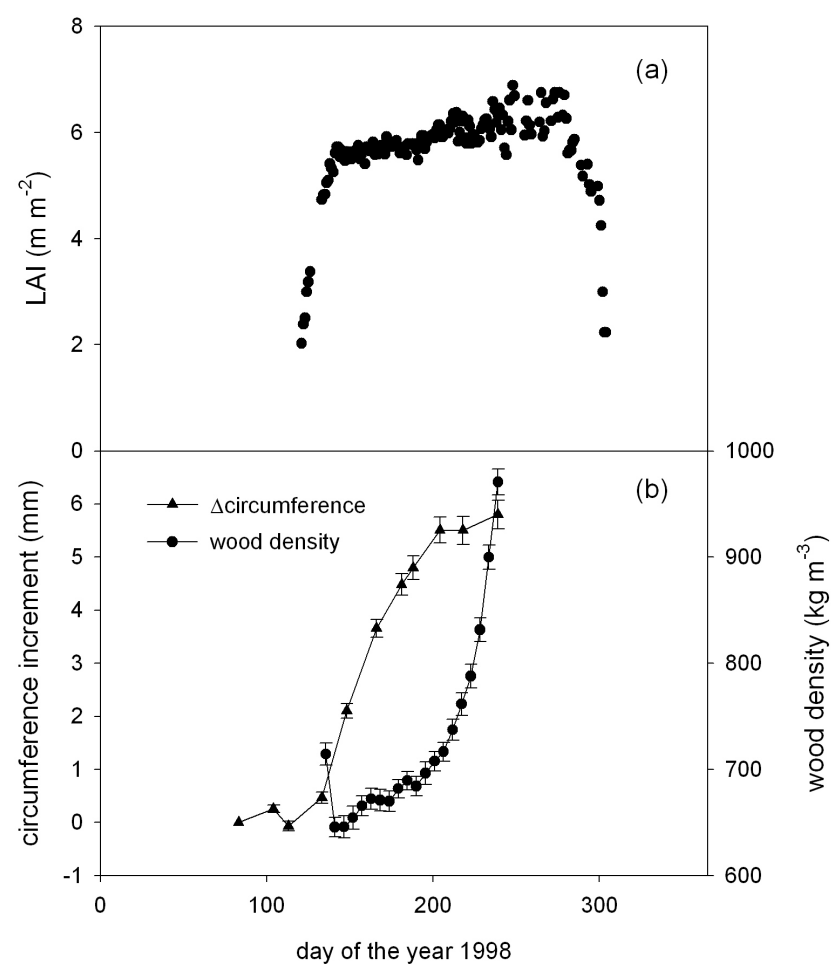

Fig. 2. Seasonal evolution of (a) leaf area index (LAI) and (b) mean circumference increment and (tree ring) wood density at the beech stand of Hesse during the experimental year 1998. Error bars indicate $\pm 1 \mathrm{SE}$.

$i$ and $i-1\left(d_{i-(i-1)}\right)$ and the average value of the stem wood density during the growing season $\left(d_{a}\right)$ :

$\alpha_{i}=\frac{d_{i-(i-1)}}{d_{a}}$

Stem wood density was derived from horizontal profiles of tree ring density, available for three years of the study period (1997, 1998 and 1999) for 32 trees sampled at breast height. Density was obtained at 20 points per year (radially equally spaced within a given annual ring) through X-ray micro densitometry analysis and cross-dated by visual superimposition with time curves of circumference increment (Bouriaud et al., 2004). An example of a typical density profile is given in Fig. 2b. For more details see Bouriaud et al. (2004).

\subsection{Annual and seasonal leaf production}

Annual leaf production was derived from oven dried $(48 \mathrm{~h}$ at $60^{\circ} \mathrm{C}$ ) leaf litterfall collected between mid-September and end-November at weekly or biweekly interval in 45 littertraps of $0.25 \mathrm{~m}^{2}$ each (Granier et al., 2008). Leaf production was expressed in $\mathrm{kg} \mathrm{Cha}^{-1} \mathrm{yr}^{-1}$ by using a C content of $48 \%$ (measured at the site; Granier unpublished).

Detailed information about leaf phenology and seasonal leaf growth was available for 1998 . Weekly values of leaf 
NPP were calculated for this year from weekly values of leaf area index (LAI; $\mathrm{m}^{2}$ leaf $\mathrm{m}^{-2}$ ground) and specific leaf area (SLA; g leaf $\mathrm{m}^{-2}$ leaf). In 1998, bud burst occurred on day of the year (DOY) 121 and leaf fall on DOY 300 (Barbaroux and Bréda 2002). During the leafy period, daily LAI (derived from canopy absorption of global radiation by using the Beer-Lambert law and an extinction coefficient of 0.4 following Granier et al., 2000) showed a sharp increase until DOY 143, a slight increase till DOY 214 and some variability around the same LAI value afterwards, likely due to minor methodological biases (Fig. 2a). Based on these observations, we assumed the LAI to increase linearly between DOY 121 and $143($ slope $=0.17)$ and 144 and $214($ slope $=0.0079)$, and be constant afterwards until DOY 300. Similar LAI pattern was reported for Hesse in 1998 by Barbaroux and Bréda (2002). Weekly values of SLA increment during leaf development were available from Davi et al. (2008). Annual maximum LAI and SLA were $6.4 \mathrm{~m}^{2} \mathrm{~m}^{-2}$ (Fig. 2a) and $43 \mathrm{~g} \mathrm{~m}^{-2}$ (Bouriaud et al., 2003), respectively.

Because this study focuses on the allocation of current photosynthates to current biomass production, the amount of previous year $\mathrm{C}$ reserves used for the construction of current leaf biomass was subtracted from the weekly values of leaf biomass production. Detailed information about these dynamics is reported by Dyckmans et al. (2000), who studied the weekly proportion of $\mathrm{C}$ reserves and new photosynthates used to produce leaves of young beeches for six weeks after bud burst. Applying the findings of Dyckmans et al. (2000) to the data of Hesse, we calculated that $80 \%$ of the leaf production in the first week after bud burst was sustained by $\mathrm{C}$ reserves but that this proportion decreases rapidly ( $47 \%$ and $35 \%$ in the second and third week, respectively) and it was negligible from the fourth week onwards.

\subsection{Notations and statistic}

Results of annual and seasonal dynamics of $\mathrm{C}$ allocation are expressed as ratios between NPP and GPP. For conciseness, the proportion of GPP allocated to leaf NPP is indicated as $\mathrm{NPP}_{\mathrm{L}}$-GPP, GPP allocated to stem as NPP as $\mathrm{NPP}_{\mathrm{S}}-\mathrm{GPP}$, GPP allocated to wood (stem plus branches and coarse roots) NPP as $\mathrm{NPP}_{\mathrm{W}}$-GPP and GPP allocated to leaf and wood NPP together as NPP $\mathrm{WL}_{\mathrm{L}} \mathrm{GPP}$.

For GPP, the significance level of interannual differences was estimated with repeated measures ANOVA (SPSS 16.0, SPSS Inc., an IBM Company, Chicago, USA). To obtain annual uncertainty values of leaf NPP, wood NPP and NPPGPP ratios, the combination of datasets with different errors (e.g. allometric relationships, stem circumferences, $\mathrm{C}$ contents, GPP) made it necessary to approximate uncertainties through error propagation, and estimate a significance difference when two derived variables with averages $m_{1}$ and $m_{2}$ (and $m_{1}<m_{2}$ ) and standard deviations $\sigma_{1}$ and $\sigma_{2}$ gave $m_{1}+1.96 \sigma_{1}<m_{2}-1.96 \sigma_{2}$. The same procedure was applied to estimate uncertainties for intra-seasonal values of
Table 2. Annual estimates of gross primary production (GPP) obtained for the forest of Hesse from eddy covariance methodology and five different flux processing methods: (i) $\mathrm{MDS}_{\mathrm{nf}}$ : nonfootprint corrected, gapfilled with marginal distribution sampling (MDS; Reichstein et al., 2005) and partitioned with short term air temperature regression (STATR; Reichstein et al., 2005); (ii) $\mathrm{ANN}_{\mathrm{nf}}$ : non-footprint corrected, gapfilled with artificial neural network (ANN; Papale et al., 2003) and partitioned with STATR; (iii) $\mathrm{MDS}_{\mathrm{f}}$ : footprint corrected, gapfilled with MDS and partitioned with STATR; (iv) $\mathrm{ANN}_{\mathrm{f}}$ : footprint corrected, gapfilled with ANN and partitioned with STATR and $(\mathrm{v}) \mathrm{L}_{\mathrm{f}}$ : footprint corrected, gapfilled and partitioned with the light-response curve model of Lasslop et al. (2010).

\begin{tabular}{lcccccccc}
\hline method & \multicolumn{8}{c}{ GPP $\left(\mathrm{MgCha}^{-1} \mathrm{yr}^{-1}\right)$} \\
& 1997 & 1998 & 1999 & 2000 & 2001 & 2002 & 2003 & 2004 \\
\hline MDS $_{\text {nf }}$ & 14.5 & 17.0 & 17.4 & 16.5 & 18.8 & 19.7 & 14.0 & 11.7 \\
ANN $_{\text {ff }}$ & 14.4 & 17.3 & 17.4 & 16.7 & 18.9 & 19.9 & 14.0 & 11.8 \\
MDS $_{\mathrm{f}}$ & 14.4 & 16.2 & 16.7 & 16.9 & 18.9 & 19.8 & 14.0 & 11.7 \\
ANN $_{\mathrm{f}}$ & 14.4 & 16.6 & 16.7 & 16.7 & 18.9 & 20.0 & 14.0 & 11.7 \\
$\mathrm{~L}_{\mathrm{f}}$ & 13.5 & 15.3 & 17.4 & 17.8 & 19.0 & 20.1 & 14.5 & 11.1 \\
\hline
\end{tabular}

$\mathrm{NPP}_{\mathrm{S}}$ and $\mathrm{NPP}_{\mathrm{S}}-\mathrm{GPP}$. Lacking access to some of the original datasets, we could not follow the same methodology to obtain uncertainties for the intra-seasonal values of $\mathrm{NPP}_{\mathrm{L}}$ and $\mathrm{NPP}_{\mathrm{L}}$-GPP. Instead, we estimated uncertainties on variables used to calculate seasonal leaf production based on typical values from the literature and expert judgment (Luyssaert et al., 2007). Uncertainty levels (standard error of the mean, $\mathrm{SE})$ were set to $5 \%$ for LAI measurements, $2.5 \%$ for SLA, $2.5 \%$ for $\mathrm{C}$ content and $25 \%$ for $\mathrm{C}$ reserve content (estimated indirectly from Dyckmans et al. (2000); see above).

The impact of environmental and stand variables on NPP, GPP and NPP-GPP ratios was evaluated via a stepwise multiple linear regression analysis with backward variable elimination using the statistical software SPSS. Thirteen potential predictive variables were tested: air temperature $\left({ }^{\circ} \mathrm{C}\right)$, precipitation $(\mathrm{mm})$, global radiation $\left(\mathrm{MJ} \mathrm{m}^{-2} \mathrm{~d}^{-1}\right)$ and drought intensity index (Bréda et al., 2006) of the currentand previous year growing season (May-August); means of air temperature, precipitation, and drought intensity index of the previous year; and tree density (tree ha ${ }^{-1}$ ) of the current and previous year. Significance thresholds of $p<0.05$ and $p<0.10$ were applied. Linear models were checked for (i) absence of multicollinearity between predictors, (ii) variation inflation factor under 1.5 for each predictor and (iii) collinearity diagnostic, with spreading of the variance proportion of each predictor on different eigenvalues. Model performance was evaluated through the explained variance $\left(R^{2}\right)$ and the $F$-value of the fitted models (Bequet et al., 2011). 


\section{Results}

\subsection{Flux analysis and impact of processing method on GPP}

The footprint analysis revealed that on average $89 \%$ (range 85-92\%) of the half-hourly NEE fluxes per year could be ascribed to the target land cover type, confirming previous reports on the high cover homogeneity at Hesse (Göckede et al., 2008). Total number of gaps in half-hourly NEE data after filtering was $\sim 30 \%$ per year. Gapfilling produced high quality data for $85 \%$ of the gaps (e.g. short gap length and high quality meteo data available for gapfilling) whereas only $15 \%$ of the gaps were filled with lower quality data (e.g. long gap length and low quality meteo data available for gapfilling). The only exception was represented by the large data gap between 26 December 1999 (when tower was destroyed by a storm, see above) and mid-April 2000 (when tower was re-constructed). However, GPP estimates were not affected by such a long gap as it was outside the growing season.

None of the methods presented systematic biases with respect to the others in estimating annual GPP. For each method, the difference in the 8 year average of annual GPP and the average across methods was $<1 \%$, whereas the largest difference in annual GPP between a single method and average across methods was $<8 \%$ (Table 2). A test revealed that removal from the analysis of GPP estimates obtained without the footprint correction (GPP-MDS ${ }_{\text {nf }}$ and GPP-ANN ${ }_{\text {nf }}$ ) does not have any relevant effect on the NPPGPP ratios and their relationship with the environment (data not shown).

The impact of the different methods to estimate GPP on the seasonal pattern of GPP was low. The difference between GPP estimates obtained with MDS and ANN was particularly low and hardly noticeable for most years (Fig. 3) which is explained by the use of the same estimates of $R_{\text {eco }}$ to derive GPP from NEE. On the other hand, larger variability was observed between the GPP- $\mathrm{L}_{\mathrm{f}}$ method and the other methods, with large deviations for 4 weeks in mid May-early June 2004 (31\% deviation; Fig. 3h), 1 week in late June 1998 and 2000 (30-35\% deviation; Fig. 3b and d) and 3 weeks in early August 1998 (33\% deviation; Fig. 3b). It should be noted that in this case the partitioning methods are completely independent because in addition to a different algorithm, the two techniques use different data for parameterization (day-time data for GPP- $\mathrm{L}_{\mathrm{f}}$, night-time data the others). Significant deviations of non-footprint-corrected GPP from footprint-corrected GPP occurred only few times during the 8 experimental years and for limited periods of maximum 2-3 weeks (data not shown).

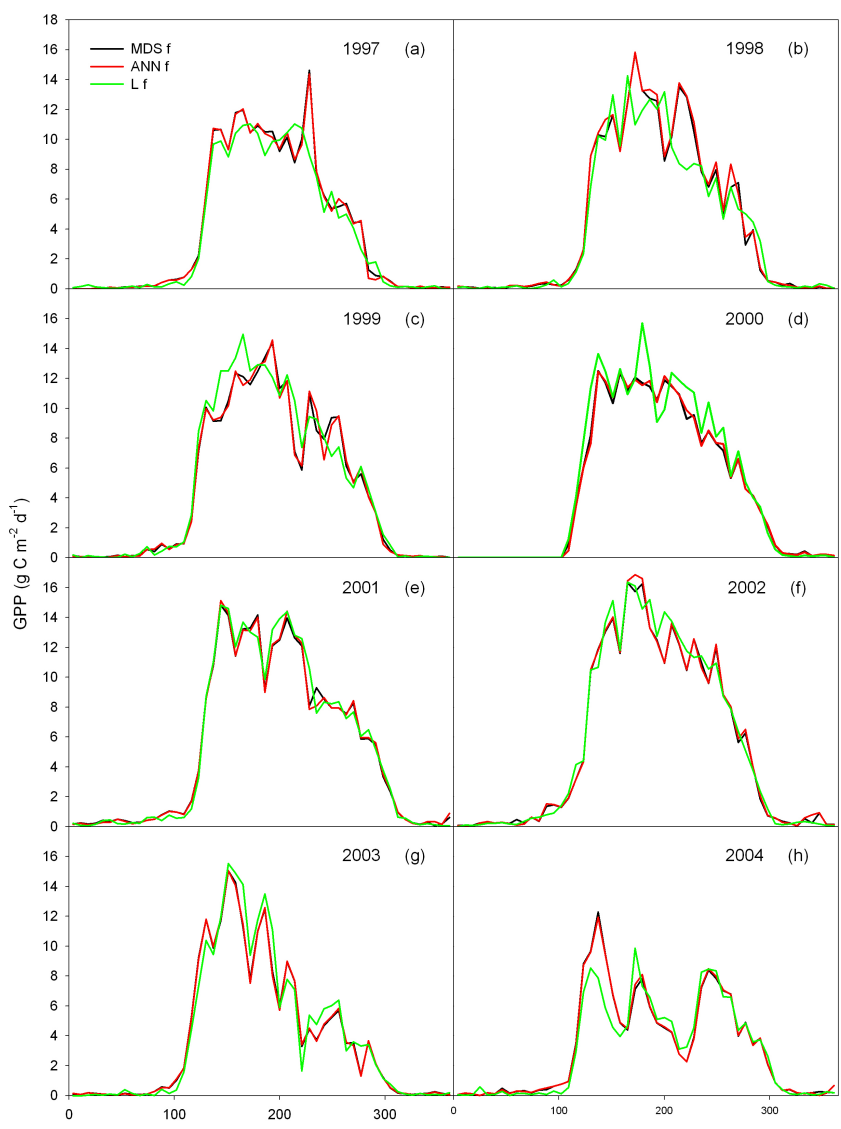

Fig. 3. Weekly values of gross primary production (GPP) for each of the 8 experimental years at the beech stand of Hesse derived from eddy covariance methodology and three flux processing methods: (i) $\mathrm{MDS}_{\mathrm{f}}$ : footprint corrected, gapfilled with marginal distribution sampling (MDS; Reichstein et al., 2005) and partitioned with short term air temperature regression (STATR; Reichstein et al., 2005); (ii) $\mathrm{ANN}_{\mathrm{f}}$ : footprint corrected, gapfilled with artificial neural network (ANN; Papale et al., 2003) and partitioned with STATR and (iii) $\mathrm{L}_{\mathrm{f}}$ : footprint corrected, gapfilled and partitioned with the light-response curve model of Lasslop et al. (2010).

\subsection{Annual production and allocation pattern}

The average annual GPP in the period 1997-2004 was 16.2 $\mathrm{MgC} \mathrm{ha}^{-1} \mathrm{yr}^{-1}$ of which 1.7 and $4.6 \mathrm{MgCha}^{-1} \mathrm{yr}^{-1}$ were invested in leaf- and wood NPP, respectively (Fig. 4a and $b$ ). The interannual variability of GPP, $\mathrm{NPP}_{\mathrm{L}}$ and $\mathrm{NPP}_{\mathrm{W}}$ is similar $(\mathrm{CV}=0.17-0.18)$, with ranges of $12-20,1.1-2.0$ and $2.9-5.4 \mathrm{MgCha}^{-1} \mathrm{yr}^{-1}$, respectively. The years $2003-$ 2004 were characterized by significantly large $\mathrm{NPP}_{\mathrm{L}}$ but low GPP and $\mathrm{NPP}_{\mathrm{W}}, 2001-2002$ by large GPP (and large $\mathrm{NPP}_{\mathrm{L}}$ for 2002) and 1999 by large $\mathrm{NPP}_{\mathrm{W}}$ and low $\mathrm{NPP}_{\mathrm{L}}$. Exceptional productivity was also recorded for 1997 (low GPP) and 1998 (low NPP ${ }_{\mathrm{W}}$ ). Multiple regression analysis showed that (i) GPP was affected by the water status of the previous year (precipitation and drought stress), (ii) $\mathrm{NPP}_{\mathrm{L}}$ by the 
Table 3. Relationships between forest production and environmental and stand variables for the beech stand of Hesse between 1997 and 2004. Results are based on correlations (Pearson correlation and multiple linear regressions) between 8 replicates of NPP, GPP and NPPGPP ratio (both for leaves, $\mathrm{NPP}_{\mathrm{L}}-\mathrm{GPP}$, and wood, $\mathrm{NPP}_{\mathrm{W}}-\mathrm{GPP}$ ) and 13 independent variables (the most important variables are: $\mathrm{TD}_{\mathrm{py}}$ : tree density previous year; $\mathrm{DI}_{\mathrm{cs}}, \mathrm{DI}_{\mathrm{ps}}$ and $\mathrm{DI}_{\mathrm{py}}$ : drought intensity index of the current growing season, previous growing season and previous year, respectively; $T_{\mathrm{cs}}, T_{\mathrm{ps}}$ and $T_{\mathrm{py}}$ : air temperature of the current growing season, previous growing season and previous year, respectively; $P_{\mathrm{ps}}$ and $P_{\mathrm{py}}$ : precipitation of the previous growing season and previous year, respectively; $R_{\mathrm{ps}}$ : global radiation of the previous growing season). Degrees of freedom are 6 for models with one predictor and 5 for models with two predictors. The $R^{2}$ is the explained variance, $F$ indicates the model prediction performance vs. the model inaccuracy and $\beta$ the standardized equation coefficients which indicate the importance of the model predictors.

\begin{tabular}{|c|c|c|c|c|c|c|}
\hline \multirow[t]{2}{*}{ dependent variable } & \multirow[t]{2}{*}{ Pearson correlation ${ }^{(a)}$} & \multicolumn{5}{|c|}{ multiple linear regression models } \\
\hline & & predictor & $p$ & $R^{2}$ & $F$ & $\beta$ \\
\hline leaf NPP & $-\mathrm{TD}_{\mathrm{py}}$ & $\mathrm{TD}_{\text {py }}$ & $<0.05$ & 0.63 & 10.1 & -0.79 \\
\hline wood NPP & $-\mathrm{DI}_{\mathrm{cs}},-T_{\mathrm{ps}},-\mathrm{DI}_{\mathrm{ps}},-\mathrm{DI}_{\mathrm{py}}$ & $\begin{array}{c}\mathrm{DI}_{\mathrm{py}} \\
\mathrm{DI}_{\mathrm{py}}, \mathrm{DI}_{\mathrm{cs}}\end{array}$ & $\begin{array}{l}<0.05 \\
<0.05\end{array}$ & $\begin{array}{l}0.55 \\
0.85\end{array}$ & $\begin{array}{c}7.3 \\
14.2\end{array}$ & $\begin{array}{c}-0.74 \\
-0.62,-0.56\end{array}$ \\
\hline GPP & $+P_{\mathrm{ps}},+P_{\mathrm{py}},-\mathrm{DI}_{\mathrm{py}}$ & $\begin{array}{c}P_{\mathrm{py}} \\
P_{\mathrm{py}}, T_{\mathrm{cs}}\end{array}$ & $\begin{array}{l}<0.05 \\
<0.05\end{array}$ & $\begin{array}{l}0.55 \\
0.92\end{array}$ & $\begin{array}{c}7.3 \\
28.0\end{array}$ & $\begin{array}{c}0.74 \\
1.97,-0.65\end{array}$ \\
\hline $\mathrm{NPP}_{\mathrm{L}}-\mathrm{GPP}$ & $+\mathrm{DI}_{\mathrm{cs}}$ & $\mathrm{DI}_{\mathrm{cS}}$ & $<0.05$ & 0.55 & 7.4 & 0.74 \\
\hline $\mathrm{NPP}_{\mathrm{W}}$-GPP & $-T_{\mathrm{ps}},-T_{\mathrm{py}}$ & $\begin{array}{c}T_{\mathrm{py}} \\
T_{\mathrm{py}}, R_{\mathrm{ps}}\end{array}$ & $\begin{array}{l}<0.10 \\
<0.10\end{array}$ & $\begin{array}{l}0.46 \\
0.84\end{array}$ & $\begin{array}{c}5.2 \\
13.1\end{array}$ & $\begin{array}{c}-0.68 \\
-0.81,-0.63\end{array}$ \\
\hline
\end{tabular}

(a) $p<0.05$

tree density of the previous year and (iii) $\mathrm{NPP}_{\mathrm{W}}$ mostly by drought stress during the current and previous year (Table 3). For each of these three productivity measures, one single predictor was able to explain 55-60\% of the data variability (Table 3). Partitioning of wood NPP into stems, branches and coarse roots was $66-69 \%, 13-15 \%$ and $18-19 \%$, respectively (Fig. 4b). Thinning in 1999 did not have a major effect on the tree standing wood biomass, which regularly increased from 1997 until 2004 (Fig. 1).

The $\mathrm{NPP}_{\mathrm{WL}}$-GPP was on average $39 \% \mathrm{yr}^{-1}$, with the largest value in $1997\left(45 \% \mathrm{yr}^{-1}\right)$ and lowest in 2001 $\left(33 \% \mathrm{yr}^{-1}\right)$ (Fig. $4 \mathrm{c}$ ). Average $\mathrm{NPP}_{\mathrm{L}}$-GPP and $\mathrm{NPP}_{\mathrm{W}}$-GPP were $11 \% \mathrm{yr}^{-1}$ and $29 \% \mathrm{yr}^{-1}$, respectively. Largest $\mathrm{NPP}_{\mathrm{L}^{-}}$ GPP and $\mathrm{NPP}_{\mathrm{W}}$-GPP was in 2003-2004 (14-15\% $\left.\mathrm{yr}^{-1}\right)$ and $1997\left(35 \% \mathrm{yr}^{-1}\right)$, respectively. Lowest $\mathrm{NPP}_{\mathrm{L}}-\mathrm{GPP}$ and $\mathrm{NPP}_{\mathrm{W}}$-GPP was in $1999\left(6 \% \mathrm{yr}^{-1}\right)$ and in 2001 and 2004

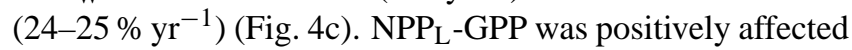
by summer drought, whereas $\mathrm{NPP}_{\mathrm{W}}$-GPP was negatively affected by the mean air temperature of the previous year (Table 3). As above for GPP and NPP, one single predictor of the constructed linear models explained about half of the data variability (Table 3 ).

\subsection{Seasonal production and allocation pattern}

The standard seasonal pattern of GPP at the Hesse forest consists of a sharp flux rate increase in late April - mid May, values around the maximum until mid August, a moderate decline until late September and a sharp decline afterwards
(Fig. 3). Whereas the GPP spring development was similar among years, the late summer decline started early, and was more pronounced, for dry years (e.g. 2001 and 2003) (Fig. 3e and g). The dry year 2004 was characterized by an anomalous low GPP in early and mid summer (Fig. 3h).

Seasonal leaf NPP in 1998 presented large rates in the last three weeks of May $\left(25-35 \mathrm{~kg} \mathrm{Cha}^{-1} \mathrm{~d}^{-1}\right)$, moderate rates in early-mid June $\left(5-15 \mathrm{~kg} \mathrm{Cha}^{-1} \mathrm{~d}^{-1}\right)$ and very low rates afterwards $\left(2 \mathrm{~kg} \mathrm{Cha}^{-1} \mathrm{~d}^{-1}\right)$ (Fig. 5a). Stem presented a similar growth pattern, with highest production rates in early season and decline afterwards. However, the growth period lasted longer, with intense growth until about mid June (45-55 $\left.\mathrm{kg} \mathrm{Cha}^{-1} \mathrm{~d}^{-1}\right)$ and low to moderate growth until late August (10-30 $\mathrm{kg} \mathrm{Cha}^{-1} \mathrm{~d}^{-1}$ ), including a break of about 2 weeks in mid-late July (Fig. 5b). Uncertainty of intraseasonal values of leaf- and wood NPP was large (Fig. 5a and b) and the abovementioned trends were not significant at $p<0.05$.

Overall, for the period between early May and mid June, the proportion of GPP allocated to leaf- and stem NPP was above $40 \% \mathrm{~d}^{-1}$, with values of about $75-85 \% \mathrm{~d}^{-1}$ in midlate May. In the following months, GPP was allocated mostly to stem production but NPPS-GPP was low $\left(<25 \% \mathrm{~d}^{-1}\right)$ and decreased along the season (Fig. $5 \mathrm{c}$ ). Maximum $\mathrm{NPP}_{\mathrm{L}}$-GPP and $\mathrm{NPP}_{\mathrm{S}}$-GPP were $33 \% \mathrm{~d}^{-1}$ and $53 \% \mathrm{~d}^{-1}$, respectively, both in mid May. As for leaf- and wood NPP, the large data uncertainty prevented the detection of significant differences in $\mathrm{NPP}_{\mathrm{L}}$-GPP and $\mathrm{NPP}_{\mathrm{S}}-\mathrm{GPP}$ within the growing season. 


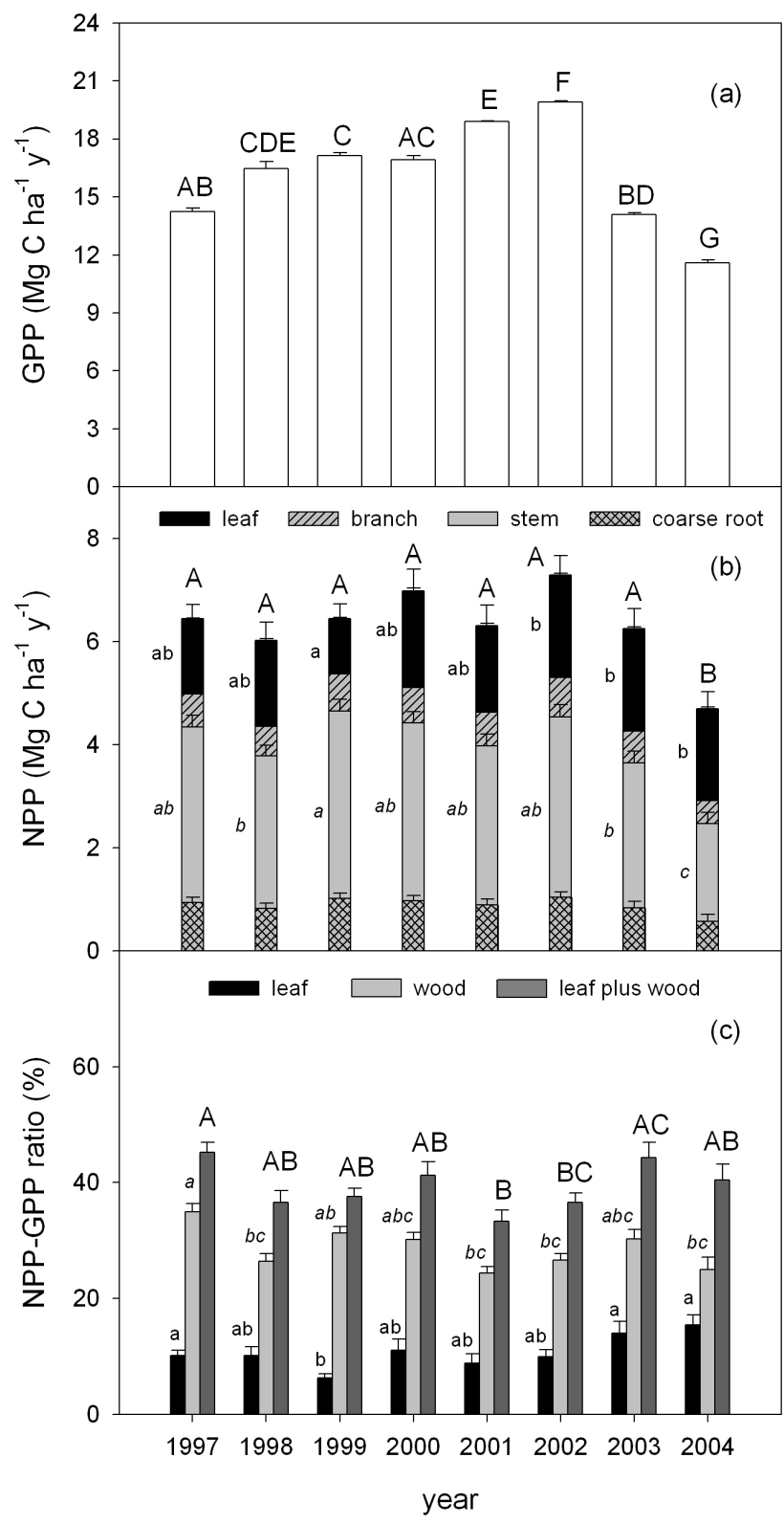

Fig. 4. Annual means of (a) gross primary production (GPP), (b) net primary production (NPP) of leaves, stem, branches and coarse roots, and (c) NPP-GPP ratio of leaves, wood (stem, branches and coarse roots, together) and leaves plus wood, for the study period. Error bars indicate $1 \mathrm{SE}$; in (b) the first horizontal cap at the top of the columns indicates SE of leaves, whereas the second horizontal cap indicates the SE of leaves plus wood. The annual value of each measured variable (GPP, NPP, NPP-GPP) is associated to a letter (or to a combination of letters) for each experimental year: lower case letters refer to leaves, lower case italics to wood and capital letters to leaves plus wood. For each organ and measured variable, lack of the same letter between years indicate a significant difference $(p<0.05)$, whereas the presence of the same letter indicate lack of significant difference.

\section{Discussion}

\subsection{Annual production}

Annual values of GPP, leaf NPP and wood NPP and their environmental drivers are similar to previous reports for Hesse and other European sites (Granier et al., 2007; Granier et al., 2008) and will not be further discussed herein; however, our study provided a detailed uncertainty analysis on productivity and associated significance level of differences among years. A significant trade off was observed between leaf NPP and wood NPP, which was associated with the opposite responses of leaves and wood to thinning (in 1999) and drought (in 2003 and 2004) (Fig. 4b, Table 3). Because of such trade offs and the uncertainties associated with NPP, interannual variability in $\mathrm{NPP}_{\mathrm{WL}}$ was mostly non-significant even for data years with marked interannual significant differences in GPP.

The low variability of GPP between different variations of gap-filling techniques, flux partitioning and footprint filters is due to the fact that, for the stand of Hesse, (i) footprint correction is of minor relevance at this relatively homogeneous site over long aggregation timescales, and (ii) the commonly used gapfilling methods MDS (Reichstein et al., 2005) and ANN (Papale et al., 2003) and partitioning methods based on short term air temperature regression (Reichstein et al., 2005) and light-response curve (Lasslop et al., 2010) do not diverge significantly among each other at the annual scale.

\subsection{Annual allocation pattern}

The average $\mathrm{NPP}_{\mathrm{L}}$-GPP $\left(11 \% \mathrm{yr}^{-1}\right)$ and $\mathrm{NPP}_{\mathrm{W}}$-GPP $\left(29 \% \mathrm{yr}^{-1}\right)$ we obtained for a young temperate beech forest compare well with previous estimates from meta-analysis of world forests (NPP $\mathrm{L}_{\mathrm{L}} \mathrm{GPP}: 4-13 \% \mathrm{yr}^{-1}$ and $\mathrm{NPP}_{\mathrm{W}}$-GPP: 8$31 \% \mathrm{yr}^{-1}$; Litton et al., 2007). Very limited knowledge was previously available on the interannual variability of NPPGPP ratio (Curtis et al., 2005) and on its environmental drivers. We found significant differences in the $\mathrm{NPP}_{\mathrm{WL}}-$ GPP ratio for a young beech stand, with differences up to $12 \% \mathrm{yr}^{-1}$. This is of high relevance as large interannual variability in $\mathrm{NPP}_{\mathrm{WL}}$-GPP might outweigh or heavily bias the differences in NPP-GPP ratio previously recorded among forests of different functional type (e.g. deciduous $\sim 56 \% \mathrm{yr}^{-1}$ vs. coniferous $\sim 42 \% \mathrm{yr}^{-1}$ ) or climate zone (e.g. boreal $\sim 37 \% \mathrm{yr}^{-1}$ vs. tropical $\sim 49 \% \mathrm{yr}^{-1}$ ) based on one or few experimental years (DeLucia et al., 2007). At Hesse, because of the low fine root production (only measured in 1997: $0.57 \mathrm{Mg} \mathrm{Cha}^{-1} \mathrm{yr}^{-1}$; Epron et al., 1999), it is very unlikely that differences in fine root NPP can offset the recorded interannual variability of $\mathrm{NPP}_{\mathrm{WL}}-\mathrm{GPP}$. For example, to offset the difference in NPP $\mathrm{WL}_{\text {-GPP }}$ between $1997\left(45 \% \mathrm{yr}^{-1}\right)$ and $2001\left(33 \% \mathrm{yr}^{-1}\right)$, fine root production should increase in 2001 by $530 \%$, which is unrealistic. 


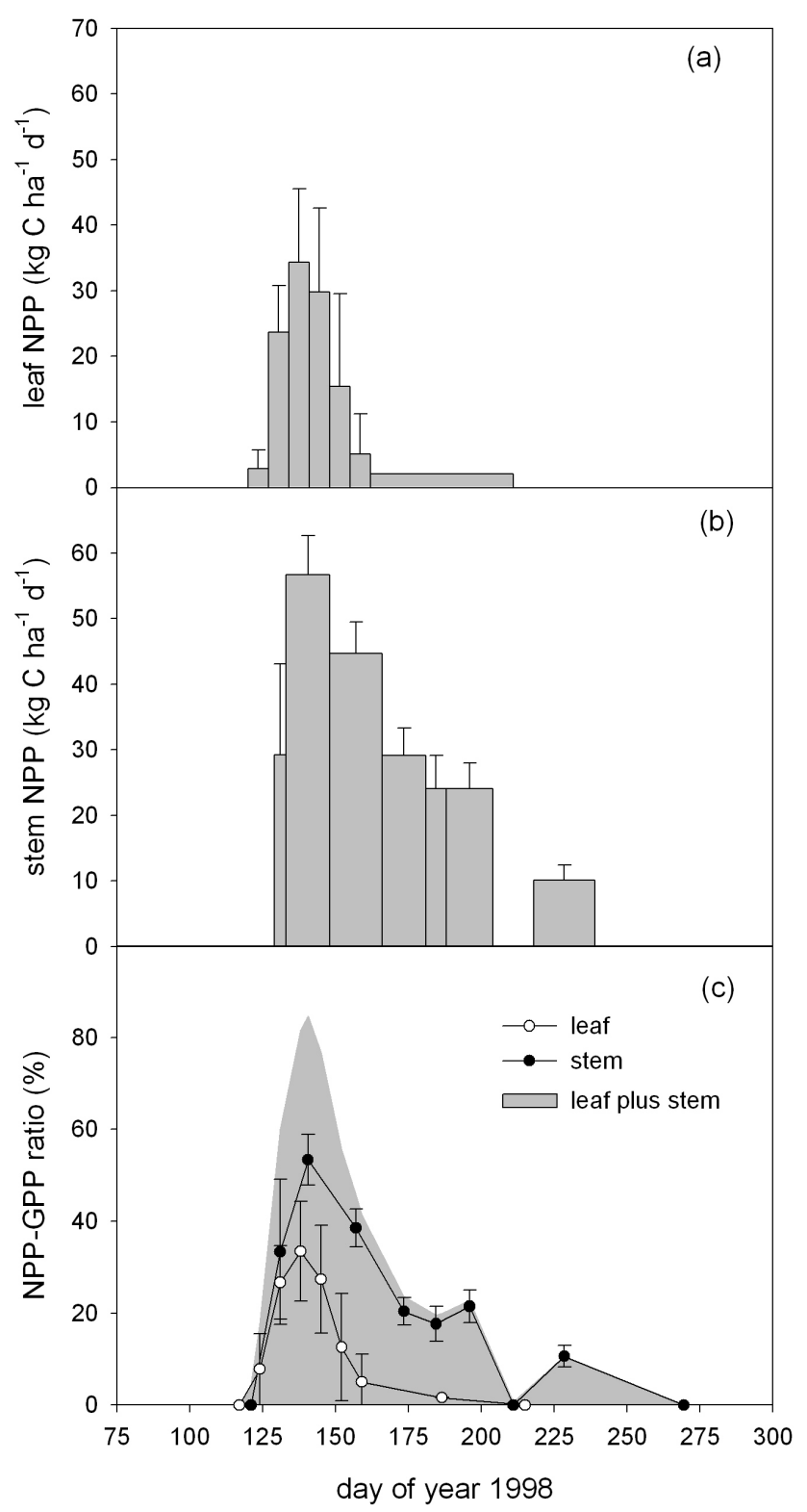

Fig. 5. Seasonal pattern of (a, b) net primary production (NPP) and (c) of the ratio NPP-GPP (GPP: gross primary production), for leaves and stems at the beech stand of Hesse in 1998. Error bars indicate $1 \mathrm{SE}$.

Variability in $\mathrm{NPP}_{\mathrm{W}}$-GPP was negatively related to previous year temperature. This can be explained by the fact that $C$ reserve accumulation might be larger in cooler years due to less autotrophic respiration (Ryan, 1991). Trees with larger $\mathrm{C}$ reserves might have an enhanced growth the next growing season, resulting in larger $\mathrm{NPP}_{\mathrm{W}}$-GPP as GPP is not affected by temperature (Table 3 ). $\mathrm{NPP}_{\mathrm{L}}$ and $\mathrm{NPP}_{\mathrm{L}}-\mathrm{GPP}$ were not affected by previous year temperature because cooler summers might result in reduced production of buds and leaf primordia (Kimura et al., 1998), partially offsetting for leaves the positive growth effect due to larger $\mathrm{C}$ reserves. The positive relationship between $\mathrm{NPP}_{\mathrm{L}}-\mathrm{GPP}$ and drought intensity of the current growing season is likely due to invariant $\mathrm{NPP}_{\mathrm{L}}$ but lower GPP in dry years (Table 3 ). In contrast to GPP, $\mathrm{NPP}_{\mathrm{L}}$ is not affected by drought because the large majority of leaf biomass is produced before the onset of drought, occurring (even for the driest years) not earlier than late June - early July at Hesse. Low NPP $\mathrm{L}_{\mathrm{LPP}}$ in 1999 is likely to be also related to the thinning in March 1999, which negatively affected leaf NPP (Table 3).

In 2003 and 2004 (years characterized by very severe and severe droughts, respectively), NPP-GPP ratios were relatively large (40-44\% $\mathrm{yr}^{-1}$ ) whereas in 1998 and 2001 (years characterized by low drought) NPP-GPP ratios were relatively low (33-37\% $\left.\mathrm{yr}^{-1}\right)$. Wood growth is more drought sensitive than photosynthesis and it is known that beech trees under low drought cease wood growth while maintaining photosynthesis (accumulating $\mathrm{C}$ reserves or investing in fine roots) (Cannel and Dewar, 1994; Leuschner et al., 2001; Barbaroux and Bréda, 2002). In case of severe drought, however, not only biomass growth is reduced, but also photosynthesis stops due to stomata closure (Granier et al., 2007). Therefore, in e.g. 2001 GPP might have been less affected by drought than wood NPP, resulting in low NPP-GPP ratio, whereas in 2004 reduction in GPP and NPP were likely to be proportional with less effect on NPP-GPP ratio (Figs. 3 and 4). This picture is complicated by interannual growth buffers (e.g. C reserves and pre-formed buds from the previous year, see above) which might explain the relatively large NPP during the extremely dry 2003.

Granier et al. (2008) estimated the autotrophic respiration $\left(R_{a}\right)$ at Hesse (1997-2004) to be on average $7.56 \mathrm{MgCha}^{-1} \mathrm{yr}^{-1}(\mathrm{SE}=0.31)$, or $52 \% \mathrm{yr}^{-1}$ of annual GPP. Although that study determined $R_{a}$ with a rather simplified approach ( $R_{a}$ as fixed proportion of the total ecosystem respiration derived from EC), it revealed that $R_{a}$ accounts for the majority of the GPP not allocated to leaf and wood NPP. Of the residual portion of GPP $(\sim 10 \%), 5 \%$ is estimated to be allocated at Hesse to fine root NPP (Granier et al., 2000; Granier et al., 2008), $2 \%\left(0.33 \mathrm{Mg} \mathrm{Cha}^{-1} \mathrm{yr}^{-1}\right)$ to fruits and turnover of small branches (Granier et al., 2008), whereas the remaining amount is hypothesized to be allocated for the production of non-structural biomass as carbohydrates of reserves (Barbaroux et al., 2003), volatile organic compounds (Guenther et al., 1995) and C transfer to ectomycorrhizal fungi (Hobbie, 2006) and root exudates (Jones et al., 2004). This list suggests that to improve our knowledge on forest $\mathrm{C}$ allocation and constraint the amount of $\mathrm{C}$ used for NPP, accurate assessments of $R_{a}$ and its interannual variability are of major relevance. 


\subsection{Seasonal allocation pattern}

Our study revealed that not only the proportion of GPP allocated to leaves but also the proportion of GPP allocated to stem wood was remarkably high in the early part of the growing season (early May - mid June), and only limited during the remaining part of the year. Deciduous trees are forced to such large GPP investment in the early season to build up the leaf canopy and best exploit the favourable conditions for $\mathrm{C}$ assimilation during this period (e.g. high radiation, mild temperature, high soil water content) and to produce the woody vessels needed to provide water and mechanical support to the newly formed leaves. For diffuse-porous species (e.g. as beech), vessel production follows the formation of the new leaves (Barbaroux and Bréda, 2002), whereas for ring-porous species (e.g. sessile oak) vessel formation precedes leaf formation (Bréda et al., 1996). Because of the extremely large GPP investment in leaves and wood, it is expected that $\mathrm{C}$ allocation to other tree organs is significantly reduced in the early growing season. For instance, fine root growth was reported to start at the site only at the end of May (Barbaroux et al., 2003), when the proportion of GPP allocated to leaves and wood is already declining.

The seasonal pattern observed for leaf- and stem NPP is typical for single leaf-flush deciduous species, except for the minor increase in leaf biomass between mid June and late July. Such early summer leaf production was related to the observed slight increase in LAI during this period (Fig. 2a) and was supported by other seasonal LAI reports for Hesse (Barbaroux and Bréda, 2002). Prolonged leaf expansion in beech has been documented also in Northern Belgium in other years (Bequet et al., 2011). The stop in stem growth in mid-late July and the low values of stem NPP in the subsequent weeks corresponded to a drought period in 1998 (Barbaroux and Bréda, 2002). In years without drought, stem NPP rates in mid July - late August are larger and stem growth ceases in late August - early September (data not shown). The recorded values of NPPS-GPP, however, might be somewhat overestimated. In fact, whereas our protocol properly took into account the contribution of previous year carbohydrates of reserve to current-year leaf production, datasets were lacking to properly estimate the contribution of carbohydrates of reserve to production of current-year stem biomass, although it has been shown that earlywood production relies partly on $\mathrm{C}$ reserve in beech (Helle and Schleser, 2004).

Although the seasonal trends of NPP and NPP-GPP ratio observed in our study are clear and consistent with textbook knowledge on tree growth dynamics, no significant differences among intra-seasonal values of NPP and NPP-GPP ratio were observed. This is due to the large uncertainty inherently associated to our methodology. Studies aiming at quantifying small differences in productivity within the growing season should therefore rely on improved protocols, considering e.g. seasonal growth dynamics at tree level (with many replicates) rather than working with stand-average tree characteristics and detailed estimates of uncertainty associated to leaf growth dynamics.

Seasonal NPP-GPP pattern are more sensitive to shortterm biases in GPP than annual NPP-GPP ratio. Our analysis on five GPP estimates determined with different flux processing methods revealed that the impact of the different methods on the overall GPP seasonal pattern was low. This agrees with results of Desai et al. (2008) who found consistent estimates of seasonal GPP pattern comparing a large set of different partitioning methods at 10 eddy-covariance sites, including Hesse. However, a more detailed analysis on finer scale revealed that, in some years, for periods of $1-$ 4 weeks, differences were reported between methods based on different partitioning algorithms, with GPP based on the light-response curve (Lasslop et al., 2010) usually lower than GPP based on the short term air temperature regression (Reichstein et al., 2005). In our study, we moderated such difference by considering an average GPP value: both partitioning methods have their advantages and limitations and it was out the scope of this manuscript to select the best GPP estimate, but they have been used to better evaluate the uncertainty in the GPP estimates. However, for more detailed studies on the seasonality of NPP-GPP ratio an extended preliminary analysis of GPP biases at the fine temporal scale is recommended.

\section{Conclusions}

Our study at a temperate beech stand provided two important new insights into the temporal variability of the NPP-GPP ratio. First, the interannual variability of the proportion of $\mathrm{C}$ allocated to leaf NPP, wood NPP and leaf plus wood NPP can be significant between years (up to $12 \% \mathrm{yr}^{-1}$ variation on the NPP-GPP ratio). This variability should be taken into account when comparing NPP-GPP ratios among forests or when using ecosystem models with fixed annual allocation scheme. Furthermore, we found that the NPP-GPP ratio significantly correlates to key environmental variables (e.g. previous year temperature but not drought for wood NPP-GPP ratio) and that lag effects between years play an important role. Second, we found that the large majority of GPP is allocated to leaf and stem NPP during the early period of the growing season (early May - mid June), whereas these sinks are of little importance in later periods of the year. Further studies on the seasonal dynamics of the NPP-GPP ratio should improve technical imperfections (e.g. possible shortterm biases in GPP estimates, contribution of previous year carbohydrates of reserve to current year stem growth, data uncertainty) before investigating the seasonal NPP-GPP ratio of other organs as branches, coarse roots and fine roots. 
Acknowledgements. This work was funded by the IWT project SimForTree (contract SBO60032) and by the European Commission, Directorate-General Research, Sixth Framework Programme (Priority area of Global Change and Ecosystems), CarboEurope IP (contract GOCE-CT-2003-505572). We thank Ivan Janssens, Johan Neirynck, Arne Verstraeten, two anonymous reviewers and the handling editor Georg Wohlfahrt for their constructive contribution and comments on a previous version of the manuscript, and Carlo Trotta for the help in the data processing.

Edited by: G. Wohlfahrt

\section{References}

Baldocchi, D. and Meyers, T.: On using eco-physiological, micrometeorological and biogeochemical theory to evaluate carbon dioxide, water vapor and trace gas fluxes over vegetation: a perspective, Agr. Forest Meteorol., 90, 1-25, 1998.

Barbaroux, C. and Bréda, N.: Contrasting distribution and seasonal dynamics of carbohydrate reserves in stem wood of adult ringporous sessile oak and diffuse-porous beech trees, Tree Physiol., 22, 1201-1210, 2002.

Barbaroux, C., Bréda, N., and Dufrene, E.: Distribution of aboveground and below-ground carbohydrate reserves in adult trees of two contrasting broad-leaved species (Quercus petraea and Fagus sylvatica), New Phytol., 157, 605-615, 2003.

Bequet, R., Campioli, M., Kint, V., Vansteenkiste, D., Muys, B., and Ceulemans, R.: Leaf area index development in temperate oak and beech forests is driven by stand characteristics and weather conditions, Trees-Struct. Funct., doi:10.1007/s00468-011-05684, 2011.

Bonan, G. B.: Forests and climate change: Forcings, feedbacks, and the climate benefits of forests, Science, 320, 1444-1449, doi:10.1126/science.1155121, 2008

Bouriaud, O., Soudani, K., and Bréda, N.: Leaf area index from litter collection: impact of specific leaf area variability within a beech stand, Can. J. Remote Sens., 29, 371-380, 2003.

Bouriaud, O., Bréda, N., Le Moguedec, G., and Nepveu, G.: Modelling variability of wood density in beech as affected by ring age, radial growth and climate, Trees-Struct. Funct., 18, 264276, doi:10.1007/s00468-003-0303-x, 2004.

Bréda, N. and Granier, A.: Intra- and interannual variations of transpiration, leaf area index and radial growth of a sessile oak stand (Quercus petraea), Ann. Sci. Forest., 53, 521-536, 1996.

Bréda, N., Huc, R., Granier, A., and Dreyer, E.: Temperate forest trees and stands under severe drought: a review of ecophysiological responses, adaptation processes and long-term consequences, Ann. For. Sci., 63, 625-644, doi:10.1051/forest:2006042, 2006.

Cannell, M. G. R. and Dewar, R. C.: Carbon allocation in trees A review of concepts for modeling, Adv. Ecol. Res., 25(25), 59104, 1994

Ciais, P., Schelhaas, M. J., Zaehle, S., Piao, S. L., Cescatti, A., Liski, J., Luyssaert, S., Le-Maire, G., Schulze, E. D., Bouriaud, O., Freibauer, A., Valentini, R., and Nabuurs, G. J.: Carbon accumulation in European forests, Nat. Geosci., 1, 425-429, doi:10.1038/ngeo233, 2008.

Curtis, P. S., Vogel, C. S., Gough, C. M., Schmid, H. P., Su, H. B., and Bovard, B. D.: Respiratory carbon losses and the carbon- use efficiency of a northern hardwood forest, 1999-2003, New Phytol., 167, 437-455, 2005.

Davi, H., Barbaroux, C., Dufrêne, E., Francois, C., Montpied, P., Brea, N., and Badeck, F.: Modelling leaf mass per area in forest canopy as affected by prevailing radiation conditions, Ecol. Model., 211, 339-349, doi:10.1016/j.ecolmodel.2007.09.012, 2008.

DeLucia, E. H., Drake, J. E., Thomas, R. B., and Gonzalez-Meler, M.: Forest carbon use efficiency: is respiration a constant fraction of gross primary production?, Glob. Change Biol., 13, 11571167, doi:10.1111/j.1365-2486.2007.01365.x, 2007.

Dyckmans, J., Flessa, H., Polle, A., and Beese, F.: The effect of elevated $\mathrm{CO}_{2}$ on uptake and allocation of C-13 and N-15 in beech (Fagus sylvatica L.) during leafing, Plant Biol., 2, 113120, 2000.

Epron, D., Farque, L., Lucot, E., and Badot, P. M.: Soil $\mathrm{CO}_{2}$ efflux in a beech forest: dependence on soil temperature and soil water content, Ann. For. Sci., 56, 221-226, 1999.

Farquhar, G. D., Caemmerer, S. V., and Berry, J. A.: A biochemicalmodel of photosynthetic $\mathrm{CO}_{2}$ assimilation in leaves of $\mathrm{C}-3$ species, Planta, 149, 78-90, 1980.

Göckede, M., Foken, T., Aubinet, M., Aurela, M., Banza, J., Bernhofer, C., Bonnefond, J. M., Brunet, Y., Carrara, A., Clement, R., Dellwik, E., Elbers, J., Eugster, W., Fuhrer, J., Granier, A., Grünwald, T., Heinesch, B., Janssens, I. A., Knohl, A., Koeble, R., Laurila, T., Longdoz, B., Manca, G., Marek, M., Markkanen, T., Mateus, J., Matteucci, G., Mauder, M., Migliavacca, M., Minerbi, S., Moncrieff, J., Montagnani, L., Moors, E., Ourcival, J.-M., Papale, D., Pereira, J., Pilegaard, K., Pita, G., Rambal, S., Rebmann, C., Rodrigues, A., Rotenberg, E., Sanz, M. J., Sedlak, P., Seufert, G., Siebicke, L., Soussana, J. F., Valentini, R., Vesala, T., Verbeeck, H., and Yakir, D.: Quality control of CarboEurope flux data - Part 1: Coupling footprint analyses with flux data quality assessment to evaluate sites in forest ecosystems, Biogeosciences, 5, 433-450, doi:10.5194/bg-5-433-2008, 2008.

Gough, C. M., Vogel, C. S., Schmid, H. P., Su, H. B., and Curtis, P. S.: Multi-year convergence of biometric and meteorological estimates of forest carbon storage, Agr. For. Meteorol., 148, 158 170, doi:10.1016/j.agrformet.2007.08.004, 2008.

Grace, J.: Understanding and managing the global carbon cycle, J. Ecol., 92, 189-202, 2004.

Granier, A., Ceschia, E., Damesin, C., Dufrêne, E., Epron, D., Gross, P., Lebaube, S., Le Dantec, V., Le Goff, N., Lemoine, D., Lucot, E., Ottorini, J. M., Pontailler, J. Y., and Saugier, B. The carbon balance of a young Beech forest, Funct. Ecol., 14, 312-325, 2000.

Granier, A., Reichstein, M., Bréda, N., Janssens, I. A., Falge, E., Ciais, P., Grunwald, T., Aubinet, M., Berbigier, P., Bernhofer, C., Buchmann, N., Facini, O., Grassi, G., Heinesch, B., Ilvesniemi, H., Keronen, P., Knohl, A., Kostner, B., Lagergren, F., Lindroth, A., Longdoz, B., Loustau, D., Mateus, J., Montagnani, L., Nys, C., Moors, E., Papale, D., Peiffer, M., Pilegaard, K., Pita, G., Pumpanen, J., Rambal, S., Rebmann, C., Rodrigues, A., Seufert, G., Tenhunen, J., Vesala, I., and Wang, Q.: Evidence for soil water control on carbon and water dynamics in European forests during the extremely dry year: 2003, Agr. Forest Meteorol., 143, 123-145, 2007.

Granier, A., Bréda, N., Longdoz, B., Gross, P., and Ngao, 
J.: Ten years of fluxes and stand growth in a young beech forest at Hesse, North-eastern France, Ann. For. Sci., 65, doi:10.1051/forest:2008052, 2008.

Guenther, A., Hewitt, C. N., Erickson, D., Fall, R., Geron, C., Graedel, T., Harley, P., Klinger, L., Lerdau, M., McKay, W. A., Pierce, T., Scholes, B., Steinbrecher, R., Tallamraju, R., Taylor, J., and Zimmerman, P.: A global-model of natural volatile organic-compounds emissions, J. Geophys. Res.-Atmos., 100, 8873-8892, 1995.

Helle, G. and Schleser, G. H.: Beyond $\mathrm{CO}_{2}$-fixation by Rubisco an interpretation of $C^{\delta 13} / C^{\delta 12}$ variations in tree rings from novel intra-seasonal studies on broad-leaf trees, Plant Cell Envir., 27, 367-380, 2004.

Hobbie, E. A.: Carbon allocation to ectomycorrhizal fungi correlates with belowground allocation in culture studies, Ecology, 87, 563-569, 2006.

Jones, D. L., Hodge, A., and Kuzyakov, Y.: Plant and mycorrhizal regulation of rhizodeposition, New Phytol., 163, 459-480, doi:10.1111/j.1469-8137.2004.01130.x, 2004.

Kimura, K., Ishida, A., Uemura, A., Matsumoto, Y., and Terashima, I.: Effects of current-year and previous-year PPFDs on shoot gross morphology and leaf properties in Fagus japonica, Tree Physiol., 18, 459-466, 1998.

Lasslop, G., Reichstein, M., Papale, D., Richardson, A. D., Arneth, A., Barr, A., Stoy, P., and Wohlfahrt, G.: Separation of net ecosystem exchange into assimilation and respiration using a light response curve approach: critical issues and global evaluation, Glob. Change Biol., 16, 187-208, 2010.

Landsberg, J. J. and Waring, R. H.: A generalised model of forest productivity using simplified concepts of radiation-use efficiency, carbon balance and partitioning, Forest Ecol. Manag., 95, 209-228, 1997.

Le Goff, N. and Ottorini, J. M.: Biomass distributions at tree and stand levels in the beech experimental forest of Hesse (NE France), Viterbo, Italy, 2000.

Le Goff, N. and Ottorini, J. M.: Root biomass and biomass increment in a beech (Fagus sylvatica L.) stand in North-East France, Ann. For. Sci., 58, 1-13, 2001.

Leuschner, C., Backes, K., Hertel, D., Schipka, F., Schmitt, U., Terborg, O., and Runge, M.: Drought responses at leaf, stem and fine root levels of competitive Fagus sylvatica L. and Quercus petraea (Matt.) Liebl. trees in dry and wet years, Forest Ecol. Manag., 149, 33-46, 2001.
Litton, C. M., Raich, J. W., and Ryan, M. G.: Carbon allocation in forest ecosystems, Glob. Change Biol., 13, 2089-2109, doi:10.1111/j.1365-2486.2007.01420.x, 2007.

Mäkelä, A. and Valentine, H. T.: The ratio of NPP to GPP: evidence of change over the course of stand development, Tree Physiol., 21, 1015-1030, 2001.

Ohtsuka, T., Saigusa, N., and Koizumi, H.: On linking multiyear biometric measurements of tree growth with eddy covariancebased net ecosystem production, Glob. Change Biol., 15, 10151024, doi:10.1111/j.1365-2486.2008.01800.x, 2009.

Papale, D., Reichstein, M., Aubinet, M., Canfora, E., Bernhofer, C., Kutsch, W., Longdoz, B., Rambal, S., Valentini, R., Vesala, T., and Yakir, D.: Towards a standardized processing of Net Ecosystem Exchange measured with eddy covariance technique: algorithms and uncertainty estimation, Biogeosciences, 3, 571-583, doi:10.5194/bg-3-571-2006, 2006.

Papale, D. and Valentini, R.: A new assessment of European forests carbon exchanges by eddy fluxes and artificial neural network spatialization, Glob. Change Biol., 9, 525-535, 2003.

Reichstein, M., Falge, E., Baldocchi, D., Papale, D., Aubinet, M., Berbigier, P., Bernhofer, C., Buchmann, N., Gilmanov, T., Granier, A., Grünwald, T., Havrankova, K., Ilvesniemi, H., Janous, D., Knohl, A., Laurila, T., Lohila, A., Loustau, D., Matteucci, G., Meyers, T., Miglietta, F., Ourcival, J. M., Pumpanen, J., Rambal, S., Rotenberg, E., Sanz, M., Tenhunen, J., Seufert, G., Vaccari, F., Vesala, T., Yakir, D., and Valentini, R.: On the separation of net ecosystem exchange into assimilation and ecosystem respiration: review and improved algorithm, Glob. Change Biol., 11, 1424-1439, doi:10.1111/j.13652486.2005.001002.x, 2005.

Ryan, M. G.: Effects of climate change on plant respiration, Ecol. Appl., 1, 157-167, 1991.

Thomson, D. J.: Criteria for the selection of stochastic models of particle trajectories in turbulent flows', J. Fluid Mech., 180, 529556, 1987.

Thornley, J. H. M. and Cannell, M. G. R.: Modelling the components of plant respiration: Representation and realism, Ann. BotLondon, 85, 55-67, 2000.

Trumbore, S.: Carbon respired by terrestrial ecosystems - recent progress and challenges, Glob. Change Biol., 12, 141-153, doi:10.1111/j.1365-2486.2005.01067.x, 2006.

Waring, R. H., Landsberg, J. J., and Williams, M.: Net primary production of forests: a constant fraction of gross primary production?, Tree Physiol., 18, 129-134, 1998. 